\title{
The seeds of success: release from fungal attack on seeds may influence the invasiveness of alien Impatiens
}

\author{
Kamil Najberek (1D) Wojciech Pusz • Wojciech Solarz • Pawel Olejniczak
}

Received: 8 May 2018/Accepted: 16 August 2018/Published online: 23 August 2018

(C) The Author(s) 2018

\begin{abstract}
Although closely related, Impatiens glandulifera and Impatiens balfourii differ in their invasiveness in Europe; only the former is highly invasive there. Following the assumptions of the enemy release hypothesis (ERH), we tested whether these differences may be explained by the levels of seed infestation by pathogenic fungi. Using seeds collected along the Swiss-Italian border, we recorded four true pathogens of seeds: Fusarium culmorum, F. oxysporum, F. sporotrichoides, and Giberella avenacea. In Italy the seeds of $I$. balfourii were infected by fungal pathogens more often than those of I. glandulifera, while in Switzerland both species were under the same level of pressure. However, the overall differences in pathogen abundance were consistent with the ERH: seeds of the more invasive species were attacked less. This could be a result of differences between the communities of fungal pathogens attacking the seeds of both species in each country. The number of colonies of secondary
\end{abstract}

Communicated by Timothy Bell.

K. Najberek $(\bowtie) \cdot$ W. Solarz · P. Olejniczak

Institute of Nature Conservation, Polish Academy of Sciences, al. Adama Mickiewicza 33, 31-120 Kraków, Poland

e-mail: najberek@iop.krakow.pl

W. Pusz

Department of Plant Protection, Wroclaw University of Environmental and Life Sciences, Plac Grunwaldzki 24A, 53-363 Wrocław, Poland pathogens (Cladosporium cladosporioides, Alternaria alternata) correlated negatively with the number of colonies of true pathogens; we suggest that the secondary pathogens may have prevented the occurrence of the true pathogens. The reason for the between-country differences in the fungal pathogen communities is unclear. A possible explanation is that Italy and Switzerland differ in their road and greenarea maintenance work schemes, which may have influenced pathogen pressure on seeds. This study is one of the few that offers results indicating that release from enemies may be crucial to the invasion success of plants as early as the seed stage.

Keywords Biological invasions - Seed enemies · Seedborne fungi $\cdot$ Seed antagonists · Obligatory pathogens $\cdot$ Enemy release hypothesis

\section{Introduction}

Biological invasions are a primary threat to biodiversity (Bellard et al. 2016; Spatz et al. 2017) and a significant cause of economic losses (Vilà et al. 2010; Pimentel 2011). According to preliminary assessments, only $1 \%$ of alien species become invasive after introduction (Williamson and Fitter 1996) but since that work was done the figure has risen to 5-20\% (Jeschke 2014). For both the theory and practice of 
nature conservation, finding out which factors determine the behavior of invasive species after they are introduced to new areas is an increasingly important task (Simberloff and Rejmánek 2011).

Vascular plants are the most intensively studied group of alien species (Pyšek et al. 2009), and those of the genus Impatiens hold a special place among them in view of their use as ornamentals, their high diversity (more than 1000 species) and the occurrence of several spectacular invasions in different parts of the world (Janssens et al. 2009; Vervoort et al. 2011). Despite the large number of studies of alien Impatiens species (e.g., Kollmann and Bañuelos 2004; Adamowski 2008; Janssens et al. 2009; Ugoletti et al. 2011; Tanner et al. 2015; Jacquemart et al. 2015; Elst et al. 2016), large questions remain, related to the great differences in invasiveness levels between closely related representatives of this genus introduced to the same region.

Two such species are $I$. glandulifera and $I$. balfourii. The former is one of the most prominent invasive alien species in Europe (Drake 2009), which resulted in introducing restrictions on its importation, possession, and trade within European Union (European Union Regulation 2014). Despite their close taxonomic relation (Janssens et al. 2009), I. balfourii is non-invasive in Europe. Its rapid expansion and negative impacts have been noted only in France, Italy, and Croatia (Banfi and Galasso 2010; Fried et al. 2014; EPPO 2018). The two species have been compared several times, and there is little evidence that the performance of $I$. balfourii is worse than $I$. glandulifera. Their photosynthetic capacity and growth rates are similar (Ugoletti et al. 2011). Both show high attractiveness to pollinators, self-compatibility, no effect of inbreeding depression (Jacquemart et al. 2015), high reproductive capacity (Ugoletti et al. 2011; Jacquemart et al. 2015), allelopathic potential (Vrchotová et al. 2011), and antimicrobial and antioxidant properties (Szewczyk et al. 2016).

The low invasiveness of $I$. balfourii has been explained by its low frost tolerance (Perrins et al. 1993; Tabak and von Wettberg 2008), which is particularly evident in mountain foothills where differences in elevation are considerable (Najberek et al. 2017). If the species indeed suffers from frosts in Europe, its spread may increase in the future with climate warming (Schmitz and Dericks 2010; Najberek et al. 2017). However, the low invasiveness of $I$. balfourii may also be a result of its low popularity as an ornamental (Adamowski 2009), limiting its propagule pressure as compared with I. glandulifera. Another suggestion offered is maladaptive habitat selection, as I. balfourii prefers roadsides where intensive mowing may create an ecological trap (Najberek et al. 2017). It is also thought that the $I$. balfourii invasion may still be in a lag phase, as it was introduced 60 years after the invasive I. glandulifera (Adamowski 2009; Ugoletti et al. 2013).

Another factor that may affect the invasiveness of alien species is lower pressure from local enemies such as predators, herbivores, or pathogens after introduction to new areas. Within their native range, species are suppressed by natural enemies. Liberation from this limiting factor in new areas may lead to rapid spread. Studies of enemies of I. glandulifera in Europe confirm that the species has been free of the impact of generalist herbivores and pathogenic fungi (Burkhart and Nentwig 2008). Impatiens balfourii has not been tested in this respect yet, but it has been demonstrated that level of its enemy release seems to depend on the habitat in which it occurs: plants growing along roadsides were attacked less than those occurring along streams, in forests and in ruderal areas (Najberek et al. 2017).

In this study we compared the levels of enemy attack in these two Impatiens species within their introduced range. We focused on the seeds. The germination behavior of alien species may influence their invasiveness (Gioria and Pyšek 2017), and it has been shown that fungal pathogens decrease the vigor of seeds (e.g., the genera Fusarium or Rhizoctonia; Lemańczyk and Sadowski 2002; Kordas et al. 2015; Pusz et al. 2016). One paper suggests that alien plants introduced to the United States from Europe are infected by $84 \%$ fewer fungi than in their natural range, which may enhance their invasiveness (Mitchell and Power 2003). In this context it is odd that the level of infestation of seeds has received little attention. Presumably this type of enemy release would be particularly beneficial to annual plants such as Impatiens, which disperse only by seeds. The antimicrobial, antioxidant, and allelopathic abilities of Impatiens make them particularly attractive study subjects (Vrchotová et al. 2011; Csiszár et al. 2012; Szewczyk et al. 2016). We hypothesized that seeds of the highly invasive I. glandulifera would be less 
attacked by fungi than seeds of the non-invasive $I$. balfourii in the introduced range of these species.

\section{Methods}

Species selected for study

\section{Impatiens glandulifera Royle}

An annual plant introduced in 1839 to Europe from the western Himalayas as an ornamental. The site of introduction was Kew Gardens in Great Britain, but the species extended its range beyond the British Isles around 1900 (Valentine 1971; Helmisaari 2010). Flowering occurs from June to October and seed set has been noted to occur from late September. Impatiens glandulifera disperses its seeds ballistically (Helmisaari 2010; Jacquemart et al. 2015). In terms of habitat preference it can be found in seminatural areas, including river valleys and forest edges, and its adaptive abilities allow it to grow in highly altered ruderal habitats such as along roads or train tracks (Helmisaari 2010).

\section{Impatiens balfourii Hook. $f$}

An annual plant introduced to Europe from the western Himalayas and Kashmir (Nasir 1980). It was cultivated first in France (Montpellier Botanic Garden) and Great Britain (Edinburgh Botanic Garden); escapes from cultivation have been noted since 1906 (Adamowski 2009). The flower and seed morphology of I. balfourii is similar to that of I. glandulifera, and it disperses its seeds ballistically (Jacquemart et al. 2015). Flowering and seed set are also comparable to $I$. glandulifera and seed set occurs in the study area in late September and October. In terms of habitat preference it may inhabit the same areas as $I$. glandulifera (Ugoletti et al. 2013) but there are some differences: I. balfourii prefers a drier substrate, while I. glandulifera occurs in moist habitats (Schmitz and Dericks 2010). In Europe both species usually occur at elevations below $1000 \mathrm{~m}$ a.s.l., whereas in their native Himalayas I. balfourii grows at 1500-2500 m a.s.1. and I. glandulifera at 1800-4000 m a.s.l. (Nasir 1980; Adamowski 2009; Helmisaari 2010).
Study area and seed collection

Seeds of both species were collected in September 2016 in Insubria, a lake region on the border of Swiss Ticino and Italian Lombardy in the foothills of the Southern Alps (Table 1; Fig. 1). The distribution of alien plants in the Alps is restricted, but the mild climate of the study area, a distinct bioclimatic region, favors biological invasions (Berger and Walther 2006; Dainese et al. 2014; Najberek et al. 2017). Both of these species are established there (Info Flora 2018).

Impatiens balfourii was more widespread in Italy than in Switzerland. We collected 2254 mature seeds of this species from four selected populations on the Italian side and from each of the only two populations found in Switzerland. Impatiens glandulifera, on the other hand, was more widespread in Switzerland. We collected 1010 mature seeds from three of the Swiss populations and from the only one found on the Italian side (Table 1; Fig. 1).

All six locations of $I$. balfourii were along roadsides - its most preferred habitat in Insubria (Najberek et al. 2017). Each of the four locations of I. glandulifera was in a different habitat: a wetland, a riverside, the Locarno airport urban area, and a roadside. Impatiens glandulifera was numerous in all surveyed habitats, and its seed weight suggested that the surveyed plants were in good condition (Table 1; Chmura et al. 2013). The collected seeds were dried at room temperature for two days and then stored in paper bags in room temperature and transported to the laboratory of the Department of Plant Protection, Wroclaw University of Environmental and Life Sciences. A month later the seeds were weighed to $0.001 \mathrm{~g}$ accuracy (PS 360.R2 scale; Table 1) in controlled conditions.

Mycological analysis

To test whether the seed surfaces and cores were attacked by fungal pathogens, mycological analyses were carried out between September and November 2016. We randomly picked 360 seeds of each species: 180 collected in Switzerland and 180 in Italy; the seeds from particular localities were pooled within country. Ninety of each 180 seeds were placed directly on petri dishes with $2 \%$ solidified maltose, 10 seeds per dish. The remaining 90 per group were disinfected with $1 \%$ sodium hypochlorite solution for $5 \mathrm{~s}$ and then treated as the previous group. Growing fungal colonies were 
identified to species level based on morphological characters. The type, color, and size of the mycelium were determined. Then microscope slides were prepared so that the spores could be measured. Their size is one of the most important characters for species identification (Pitt and Hocking 2009; Watanabe 2011). Most frequently either one colony or none grew on a single seed. Two or more colonies were recorded occasionally. In those cases the shape of the colonies indicated unequivocally their independent origin, so the number of colonies could be reliably assessed. The colonies of fungal taxa in each petri dish were counted and summed.

Since our study focused on assessing the potential negative impact of enemies on seeds of both Impatiens species, we classified the recorded fungal species as true pathogens or secondary pathogens, and used only the former group in the tests. The group includes obligatory pathogens with invariably negative impacts on plants and their seeds, effects documented in the literature (de Wit 2007). Secondary pathogens are generally less harmful and in some circumstances their presence may even benefit a plant by limiting its infestation by true pathogens (Liggitt et al. 1997).

\section{Statistical analysis}

The Impatiens species, country of origin, and seed treatment (disinfected or non-disinfected) were used as factors in a $2 \times 2 \times 2$ full-factorial design. To test for the differences between species and between countries a generalized linear model (GLM) was used.
Fig. 1 Localities of the sampled populations of Impatiens glandulifera and I. balfourii on the Swiss-Italian border

The number of fungal colonies per petri dish was incorporated in the model as the response variable. Since the number of colonies could exceed the number of seeds on the dish, the variable was assumed to be Poisson-distributed, with the logarithm as the link function. The relationship between numbers of colonies of fungal species was analyzed with the use of Spearman non-parametric correlations. All statistical analyses employed SPSS ver. 24.0 (IBM Corp. 2016).

\section{Results}

The seeds were inhabited by 14 fungal species, 13 of which were isolated from non-disinfected seeds (Table 2). Four of them were true pathogens of seeds: Fusarium culmorum, F. oxysporum, F. sporotrichoides, and Giberella avenacea (Lemańczyk and Sadowski 2002; Schaafsma et al. 2005; Kordas et al. 2015; Gołębiowska et al. 2016; Pusz et al. 2016). Disinfected seeds were attacked by only 6 species (Table 3), only one of which (Cladosporium herbarum) was not found earlier in the non-disinfected seeds. No true pathogens were found in disinfected seeds. The most numerous fungal species in both treatments was C. cladosporioides. Both Cladosporium species are considered to be secondary pathogens

Table 1 Localities, habitats, number of collected seeds and their average weight (AVG) in samples from Impatiens glandulifera and I. balfourii populations on the Swiss-Italian border

\begin{tabular}{|c|c|c|c|c|}
\hline Species & Locality & Habitat & $N$ seeds & Mean seed weight $(\mathrm{g})$ \\
\hline \multirow[t]{4}{*}{ I. glandulifera } & Switzerland, Bolle di Magadino Nature Reserve & Wetland & 60 & 0.010 \\
\hline & Switzerland, Bolle di Magadino Nature Reserve & Riverside & 60 & 0.011 \\
\hline & Switzerland, Locarno airport & Airport & 60 & 0.011 \\
\hline & Italy, Germignaga & Roadside & 180 & 0.012 \\
\hline \multirow[t]{6}{*}{ I. balfourii } & Switzerland, Monteggio & Roadside & 90 & 0.005 \\
\hline & Switzerland, Ponte Brolla & Roadside & 90 & 0.004 \\
\hline & Italy, near Musignano & Roadside & 45 & 0.004 \\
\hline & Italy, Pino Sulla Sponda del Lago Maggiore & Roadside & 45 & 0.004 \\
\hline & Italy, Pino Sulla Sponda del Lago Maggiore & Roadside & 45 & 0.004 \\
\hline & Italy, Lavena Ponte Tresa & Roadside & 45 & 0.003 \\
\hline
\end{tabular}




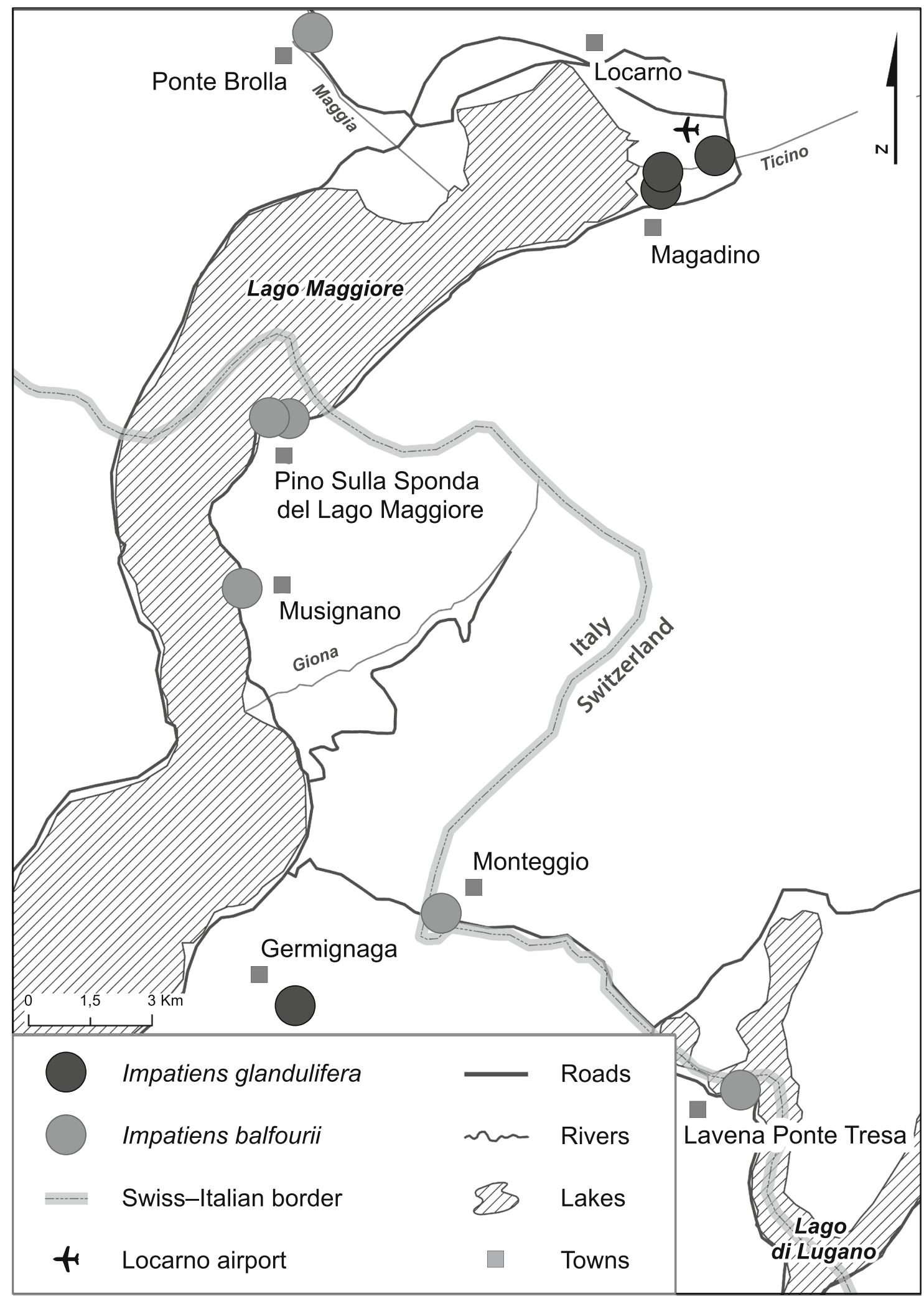


Table 2 Number of colonies of fungal species isolated from nondisinfected seeds of Impatiens glandulifera and I. balfourii, collected in Switzerland and Italy

Names of true pathogens are bolded

Table 3 Number of colonies of fungal species isolated from disinfected seeds of Impatiens glandulifera and $I$. balfourii, collected in Switzerland and Italy

\begin{tabular}{|c|c|c|c|c|}
\hline \multirow[t]{2}{*}{ Species } & \multicolumn{2}{|c|}{ I. glandulifera } & \multicolumn{2}{|l|}{ I. balfourii } \\
\hline & Switzerland & Italy & Switzerland & Italy \\
\hline Alternaria alternata & 14 & 41 & 25 & 1 \\
\hline Aspergillus niger & 0 & 2 & 0 & 1 \\
\hline Cladosporium cladosporioides & 64 & 45 & 60 & 5 \\
\hline Epicoccum nigrum & 5 & 1 & 0 & 0 \\
\hline Fusarium culmorum & 7 & 0 & 0 & 0 \\
\hline Fusarium oxysporum & 0 & 0 & 1 & 2 \\
\hline Fusarium sporotrichoides & 0 & 0 & 0 & 1 \\
\hline Giberella avenacea & 0 & 0 & 6 & 28 \\
\hline Penicillium notatum & 0 & 3 & 0 & 7 \\
\hline Penicillium urticae & 0 & 0 & 2 & 40 \\
\hline Phoma leveillei & 0 & 1 & 0 & 0 \\
\hline Trichoderma harzianum & 0 & 0 & 0 & 6 \\
\hline Trichoderma viridae & 0 & 2 & 0 & 0 \\
\hline
\end{tabular}

\begin{tabular}{llllll}
\hline Species & \multicolumn{2}{l}{ I. glandulifera } & & \multicolumn{2}{l}{ I. balfourii } \\
\cline { 2 - 3 } & Switzerland & Italy & & Switzerland & Italy \\
\hline Alternaria alternata & 7 & 1 & 0 & 2 \\
Aspergillus niger & 0 & 0 & 0 & 3 \\
Cladosporium cladosporioides & 14 & 0 & 7 & 8 \\
Cladosporium herbarum & 0 & 6 & 0 & 0 \\
Epicoccum nigrum & 1 & 0 & & 0 & 8 \\
Penicillium notatum & 0 & 0 & & 1 & 0 \\
\hline
\end{tabular}

and saprotrophs (Stone et al. 2000). Alternaria alternata, Aspergillus niger, Phoma leveillei, Penicillium, and Trichoderma are also classified as secondary pathogens (McRoberts and Lennard 1996; Stone et al. 2000; Tekaia and Latgé 2005; Aveskamp et al. 2008; Pusz et al. 2016).

Correlation tests revealed that the number of colonies of $C$. cladosporioides (secondary pathogen, saprotroph) in non-disinfected seeds correlated negatively with the combined number of colonies of true pathogen species $\left(r_{\mathrm{S}}=-0.528, p<0.001, N=36\right)$. Moreover, the number of $C$. cladosporioides colonies in non-disinfected seeds correlated positively with the number of colonies of another secondary pathogen, $A$. alternata $\left(r_{\mathrm{S}}=0.388, p<0.05, N=36\right)$.
Enemy attack assessments

Only true pathogens (F. culmorum, F. oxysporum, $F$. sporotrichoides, $G$. avenacea) were included in the tests. Overall, I. glandulifera seeds were less affected than $I$. balfourii seeds by these fungi $(B=1.692$, $p<0.001, \mathrm{df}=1)$. In seeds sourced from Italy, enemy pressure was substantially higher on $I$. balfourii $(B=-1.488, p<0.001$, df $=1$, Fig. 2$)$, while in seeds sourced from Switzerland the level of enemy attack was similar for the two Impatiens species $(B=0.000$, NS, df $=1$, Fig. 2).

\section{Discussion}

Among the many published tests of the influence of enemy pressure on alien plants invasion success there are only a few such studies of plant seeds. Blaney and 


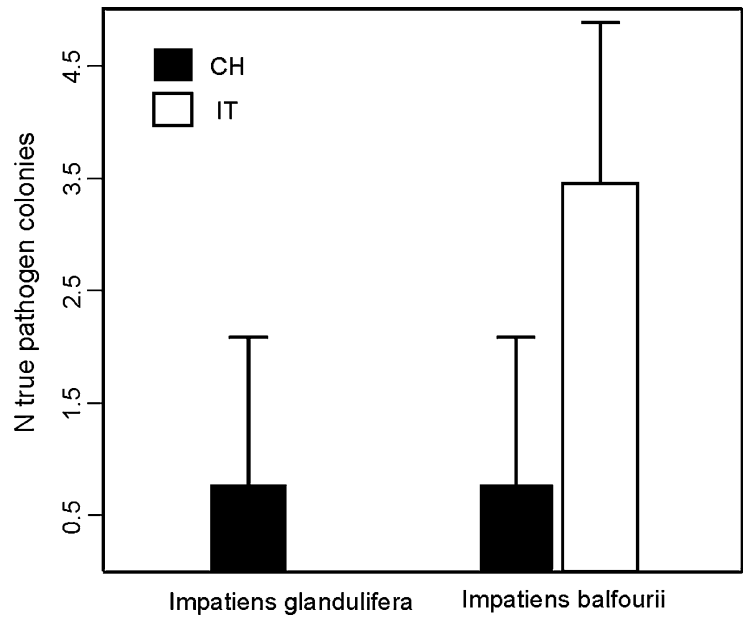

Fig. 2 Mean number of true pathogen colonies per petri dish $( \pm \mathrm{SE})$ recorded on non-disinfected seeds of Impatiens glandulifera and I. balfourii, sourced from Switzerland $(\mathrm{CH})$ and Italy (IT)

Kotanen (2001) used fungicide treatments to estimate the impact of soil fungi on seeds. They compared seed germination success in natural soil and soil with added fungicide. Their results did not differ between alien and native plant seeds. Beckstead and Parker (2003) used soil sterilization to test the effect of belowground pathogens on seeds, comparing seed germination, seedling survival and the growth of the invasive alien Ammophila arenaria in its native European and introduced North American range. They found that seed germination and seedling survival decreased in the non-sterilized soil, but no evidence of differences in release from natural enemies between the two ranges. They did, however, find that in the introduced range the seedlings and rhizosphere had no pathogenic nematodes. Other studies have noted limiting effects of soil pathogens on plant seedlings in their native range (Packer and Clay 2000; Reinhart et al. 2003; Callaway et al. 2004), suggesting that belowground organisms may also affect invasion success.

Our study concentrated on two alien Impatiens species that are closely related but surprisingly different in their invasiveness in Europe. Impatiens glandulifera is an invasive alien species, while $I$. balfourii is non-invasive. In this respect our assessment of the level of enemy attack broadens the traditional enemy release tests called for by the enemy release hypothesis (ERH; Elton 1958; Maron and Vilà 2001; Keane and Crawley 2002), because we studied the two alien species only in their introduced range and did not include native species. We expected the invasive alien species to be attacked by enemies at lower intensity than the non-invasive alien, an assumption similar to that of the ERH hypothesis which postulates that invasive alien species are under lower enemy pressure than native ones.

True pathogens such as the Fusarium species recorded in our study significantly reduce the quality of seeds (Lemańczyk and Sadowski 2002; Kordas et al. 2015; Pusz et al. 2016). Giberella avenacea is another important true fungal pathogen of plants, harmful to seeds of various plant species (Schaafsma et al. 2005; Gołębiowska et al. 2016). We excluded the secondary and saprotrophic fungi from the tests because their impact is uncertain; their presence can be neutral or even beneficial to a plant, so they cannot be automatically classified as enemies. For example, it is known that species of Cladosporium (the genus most frequently found in our study) have negative effects on seeds of many plant species (Waqas et al. 2013) but that they help limit the occurrence of a much more harmful genus - Fusarium (Liggitt et al. 1997). The latter effect is supported by our finding of a negative correlation between the occurrence of $C$. cladosporioides and the occurrence of true pathogens.

The two Impatiens species we used to compare the level of pressure from true pathogens differ in their invasiveness. Thus, the success of the highly invasive I. glandulifera would be attributable to better release from enemies than the non-invasive $I$. balfourii. In considering the between-country differences, however, the dependence of invasiveness on the release from enemy pressure is less straightforward. In Italy, $I$. balfourii was attacked by true pathogens substantially more often than I. glandulifera was, while in Switzerland the seeds of the two species were under the same level of pressure. It would seem that the assumption that invasive alien species are under lower enemy pressure than non-invasive ones was fully confirmed only on the Italian side of the border.

This disparity could be a result of differences between the communities of fungal pathogens that colonized seeds of both species in Italy and Switzerland. It should be stressed that we isolated true pathogens only from non-disinfected seeds. This manifestation of pathogen resistance may reflect the antimicrobial, antioxidant, and/or allelopathic abilities of these plants (Vrchotová et al. 2011; Csiszár et al. 
2012; Szewczyk et al. 2016). However, an alternative explanation can be inferred from our finding that the number of colonies of the most numerous species, $C$. cladosporioides, correlated negatively with the number of colonies of true pathogens. This secondary pathogen may have prevented the true pathogens from penetrating the seed core. Cladosporium cladosporioides correlated positively with another secondary pathogen, A. alternata, which has been found to reduce the true pathogen $F$. culmorum (Liggitt et al. 1997). Both of these secondary pathogens may have suppressed the true pathogens efficiently enough to keep the seed cores unaffected. It could also explain the contrasting ERH test results: non-disinfected seeds of $I$. balfourii from Italy were almost free of $C$. cladosporioides or A. alternate; therefore the level of enemy pressure in that case was highest; at the same time, the number of colonies of both secondary pathogens was highest in Italian seeds of I. glandulifera, and these seeds were not affected by true pathogens at all. Moreover, the seeds of both species collected on the Swiss side were under similar enemy pressure, a finding related to their comparable levels of secondary pathogen occurrence. The reason for this Swiss/Italian divergence of the fungal pathogen communities is unclear. The big difference in the number of colonies of $C$. cladosporioides and A. alternata was found for seeds of the Impatiens species collected from the Italian roadsides. Swiss seeds of the two species showed similar results for that parameter, regardless of habitat, meaning that their levels of pathogen pressure probably did not depend on the type of habitat from which the seeds were collected.

Another possible explanation for the disparate results is that the two studied countries substantially differ in their road and green-area maintenance work schemes. In Switzerland these areas are frequently mowed and raked, and the cuttings are scrupulously removed, all of which helps limit the invasion success of any alien plant species, especially annuals such as Impatiens (Najberek et al. 2017). That maintenance work may also have a significant effect on the extent of true pathogen attack: the abundance of such pathogens in well-tended localities of I. balfourii in Switzerland could be lower. Impatiens glandulifera, the species more frequently found in Switzerland than in Italy, may have been exposed to relatively high levels of true pathogens on the Swiss side, because the studied plants were collected mainly from less-mowed areas and were therefore less affected by maintenance work (e.g., in the Bolle di Magadino Nature Reserve). The $I$. balfourii seeds from Switzerland were obtained exclusively along roadsides. A difference in pathogen abundance between the studied habitats may explain the lack of differences in infestation levels between the studied species on the Swiss side. In Italy, where the seeds of both species were collected from roadsides, the difference in the number of true pathogens on seeds was pronounced, with a lower level of attack on the invasive I. glandulifera, supporting the assumption of an inverse relation between enemy attack and invasiveness.

Seeds of I. balfourii were under the highest pathogen pressure in Italy. At the same time, however, I. balfourii was more numerous on the Italian side (Najberek et al. 2017), so it may be that the impact of the recorded true pathogens on these Impatiens seeds is not always as harmful as expected (Lemańczyk and Sadowski 2002; Gołębiowska et al. 2016). It is worth stressing that true pathogens were recorded only from non-disinfected seeds; the cores of the seeds of both Impatiens species were not affected. Further studies would be required to find out whether the germination success of I. balfourii and I. glandulifera does depend on attack by true pathogens. Pathogens may decrease the viability of seeds already in the dormant stage but also during germination. Germinating seed shells lose their integrity, and this may facilitate the penetration of pathogens to the core, affecting seedling performance.

Tests of the influence of enemy attack on invasiveness mainly compare the pressure exerted by enemies on native versus alien species; they pay less attention to the origin of these enemies (e.g., Tanner et al. 2015). A clear distinction between native and alien enemies would help to further clarify the evolution of plantpest interactions, but it is notoriously difficult to assess the origin of small organisms, including pathogens. Primary occurrence data are very scarce for many such species, and their human-mediated transport to new areas is accidental and thus poorly documented (Pociecha et al. 2016; Solarz and Najberek 2017; Solarz et al. 2017). The origin of Fusarium oxysporum, the true pathogen identified from Italian and Swiss I. balfourii seeds, seems open to question. It is classified as an alien in Europe in the DAISIE database (2018) but there are more than 120 different formae speciales of F. oxysporum (Michielse and Rep 2009) and probably only a few of them are not native to 
Europe. Further studies are required to establish the origin of this true pathogen.

\section{Conclusions}

Our present results of enemy attack tests are among the very few that come from a study of plant seeds. Release from enemies appears to be an important element of the mechanism behind the success of I. glandulifera in Europe, a mechanism which, we showed, begins to operate as early in the plants' life cycle as the seed stage. Further studies of this mechanism are needed, including assessments of the direct impact of true pathogens on seeds and on seedling fitness, as well as the interplay between communities of secondary and true pathogens and between habitat types.

Impatiens balfourii may become a much larger management problem in the future (Ugoletti et al. 2011; Jacquemart et al. 2015; Najberek et al. 2017), necessitating more studies of this species, better monitoring of its spread, and stronger measures to prevent new introductions of I. balfourii and to contain it in the areas where it was introduced in the past, with complete eradication as the preferred outcome. Further delay is likely to result in its spread to the point that effective control will be impossible (Najberek et al. 2017).

Acknowledgements This work was supported by the Institute of Nature Conservation, Polish Academy of Sciences (Kraków, Poland) through grant funding for young scientists, by COST Action TD1209 (Short Term Scientific Mission, Reference code: ECOST-STSM-TD1209-140915-062069) and by the National Science Centre of Poland under Grant Number N N304 3092 40. We thank Michael Jacobs for comments and for line-editing the paper for submission.

Open Access This article is distributed under the terms of the Creative Commons Attribution 4.0 International License (http:// creativecommons.org/licenses/by/4.0/), which permits unrestricted use, distribution, and reproduction in any medium, provided you give appropriate credit to the original author(s) and the source, provide a link to the Creative Commons license, and indicate if changes were made.

\section{References}

Adamowski W (2008) Balsams on the offensive: the role of planting in the invasion of Impatiens species. In: Plant invasions: human perceptron, ecological impacts and management. Backhuys Publishers, Leiden, pp 57-70

Adamowski W (2009) Impatiens balfourii as an emerging invader in Europe. Neobiota 8:183-194

Aveskamp MM, De Gruyter J, Crous PW (2008) Biology and recent developments in the systematics of Phoma, a complex genus of major quarantine significance. Fungal Divers 31:1-18

Banfi E, Galasso G (2010) La flora esotica Lombarda. Regione Lombarda. Comune di Milano. Museo Civico di Storia Naturale di Milano, Milano, p 273

Beckstead J, Parker IM (2003) Invasiveness of Ammophila arenaria: release from soil-borne pathogens. Ecology 84:2824-2831

Bellard C, Cassey P, Blackburn TM (2016) Alien species as a driver of recent extinctions. Biol Lett 12:20150623

Berger S, Walther G-R (2006) Distribution of evergreen broadleaved woody species in Insubria in relation to bedrock and precipitation. Bot Helv 116:65-77

Blaney CS, Kotanen PM (2001) Effects of fungal pathogens on seeds of native and exotic plants: a test using congeneric pairs. J Appl Ecol 38:1104-1113

Burkhart K, Nentwig W (2008) Control of Impatiens glandulifera (Balsaminaceae) by antagonists in its invaded range? Invasive Plant Sci Manag 1:352-358

Callaway RM, Thelen GC, Rodriguez A, Holben WE (2004) Soil biota and exotic plant invasion. Nature 427:731-733

Chmura D, Csontos P, Sendek A (2013) Seed mass variation in central European populations of invasive Impatiens glandulifera Royle. Pol J Ecol 61:805-809

Corp IBM (2016) IBM SPSS statistics for windows, version 24. IBM Corp, Armonk

Csiszár Á, Korda M, Schmidt D, Šporčić D, Teleki B, Tiborcz V, Zagyvai G, Bartha D (2012) Study on allelopathic potential of some invasive and potentially invasive neophytes. In: International scientific conference on sustainable development \& ecological footprint, 26-27 March 2012, Sopron, Hungary

Dainese M, Kühn I, Bragazza L (2014) Alien plant species distribution in the European Alps: influence of species' climatic requirements. Biol Invasions 16:815-831

DAISIE (2018) Daisie European invasive alien species gateway. http://www.europe-aliens.org/speciesFactsheet. do?speciesId=17367\#. Accessed 01 May 2018

de Wit PJGM (2007) How plants recognize pathogens and defend themselves. Cell Mol Life Sci 64:2726-2732

Drake JA (ed) (2009) DAISIE Handbook of alien species in Europe. Invading nature - Springer series in invasion ecology, vol 3. Springer, Dordrecht, p 399

Elst EM, Acharya KP, Dar PA, Reshi ZA, Tufto J, Nijs I, Graae BJ (2016) Pre-adaptation or genetic shift after introduction in the invasive species Impatiens glandulifera? Acta Oecol 70:60-66

Elton CS (1958) The ecology of invasions by animals and plants. Methuen, London

EPPO (2018) EPPO global database. https://gd.eppo.int. Accessed 01 Mar 2018

European Union Regulation (2014) Regulation No 1143/2014 of the European Parliament and of the Council of 22 October 2014 on the prevention and management of the 
introduction and spread of invasive alien species. Off J Eur Union 57:35

Fried G, Laitung B, Pierre C, Chagué N, Panetta FD (2014) Impact of invasive plants in Mediterranean habitats: disentangling the effects of characteristics of invaders and recipient communities. Biol Invasions 16:1639-1658

Gioria M, Pyšek P (2017) Early bird catches the worm: germination as a critical step in plant invasion. Biol Invasions 19:1055-1080

Gołębiowska H, Pląskowska E, Weber R, Kieloch R (2016) The effect of soil tillage and herbicide treatments on the incidence of Fusarium fungi genus in the grain of rye. Plant Soil Environ 62:435-440

Helmisaari H (2010) NOBANIS - invasive alien species fact sheet - Impatiens glandulifera. https://www.nobanis.org/. Accessed 20 Apr 2018

Info Flora (2018) Info flora database. https://www.infoflora.ch/ en/. Accessed 10 Apr 2018

Jacquemart A-L, Somme L, Colin C, Quinet M (2015) Floral biology and breeding system of Impatiens balfourii (Balsaminaceae): an exotic species in extension in temperate areas. Flora-Morphol Distrib Funct Ecol Plants 214:70-75

Janssens SB, Knox EB, Huysmans S, Smets EF, Merckx VSFT (2009) Rapid radiation of Impatiens (Balsaminaceae) during Pliocene and Pleistocene: result of a global climate change. Mol Phylogenet Evol 52:806-824

Jeschke JM (2014) General hypotheses in invasion ecology. Divers Distrib 20:1229-1234

Keane RM, Crawley MJ (2002) Exotic plant invasions and the enemy release hypothesis. Trends Ecol Evol 17:164-170

Kollmann J, Bañuelos MJ (2004) Latitudinal trends in growth and phenology of the invasive alien plant Impatiens glandulifera (Balsaminaceae). Divers Distrib 10:377-385

Kordas L, Pusz W, Czapka T, Kacprzyk R (2015) The effect of low-temperature plasma on fungus colonization of winter wheat grain and seed quality. Pol $\mathrm{J}$ Environ Stud 24:433-438

Lemańczyk G, Sadowski CK (2002) Fungal communities and health status of roots of winter wheat cultivated after oats and oats mixed with other crops. Biocontrol 47:349-361

Liggitt J, Jenkinson P, Parry DW (1997) The role of saprophytic microflora in the development of Fusarium ear blight of winter wheat caused by Fusarium culmorum. Crop Prot 16:679-685

Maron JL, Vilà M (2001) When do herbivores affect plant invasion? Evidence for the natural enemies and biotic resistance hypotheses. Oikos 95:361-373

McRoberts N, Lennard JH (1996) Pathogen behaviour and plant cell reactions in interactions between Alternaria species and leaves of host and nonhost plants. Plant Pathol 45:742-752

Michielse CB, Rep M (2009) Pathogen profile update: Fusarium oxysporum. Mol Plant Pathol 10:311-324

Mitchell CE, Power AG (2003) Release of invasive plants from fungal and viral pathogens. Nature 421:625-627

Najberek K, Nentwig W, Olejniczak P, Król W, Baś G, Solarz W (2017) Factors limiting and promoting invasion of alien Impatiens balfourii in Alpine foothills. Flora-Morphol Distrib Funct Ecol Plants 234:224-232

Nasir YJ (1980) Balsaminaceae. Flora of Pakistan. Agricultural Research Councils, Islamabad, pp 1-17
Packer A, Clay K (2000) Soil pathogens and spatial patterns of seedling mortality in a temperate tree. Nature 404:276-278

Perrins J, Fitter A, Williamson M (1993) Population biology and rates of invasion of three introduced Impatiens species in the British Isles. J Biogeogr 20(1):33-44

Pimentel D (2011) Biological invasions: economic and environmental costs of alien plant, animal, and microbe species. CRC Press, Boca Raton

Pitt JI, Hocking AD (2009) Fungi and food spoilage. Springer, New York

Pociecha A, Solarz W, Najberek K, Wilk-Woźniak K (2016) Native, alien, cosmopolitan, or cryptogenic? A framework for clarifying the origin status of rotifers. Aquat Biol 24:141-149

Pusz W, Mascher F, Czembor E, Czembor J, Ogórek R (2016) Characterization of the relationships between wheat cultivars, fusarium head blight, and mycoflora grains. Pol J Environ Stud 25:1373-1380

Pyšek P, Lambdon PW, Arianoutsou M, Kühn I, Pino J, Winter M (2009) Alien vascular plants of Europe. In: Drake JA (ed) DAISIE Handbook of alien species in Europe. Invading nature - Springer series in invasion ecology, vol 3. Springer, Dordrecht, pp 43-61

Reinhart KO, Packer A, Van der Putten WH, Clay K (2003) Plant-soil biota interactions and spatial distribution of black cherry in its native and invasive ranges: soil biota facilitates invasion of a non-native tree. Ecol Lett 6:1046-1050

Schaafsma AW, Tamburic Ilincic L, Hooker DC (2005) Effect of previous crop, tillage, field size, adjacent crop, and sampling direction on airborne propagules of Gibberella zeae/Fusarium graminearum, fusarium head blight severity, and deoxynivalenol accumulation in winter wheat. Can J Plant Pathol 27:217-224

Schmitz U, Dericks G (2010) Spread of alien invasive Impatiens balfourii in Europe and its temperature, light and soil moisture demands. Flora-Morphol Distrib Funct Ecol Plants 205:772-776

Simberloff D, Rejmánek M (2011) Encyclopedia of biological invasions. University of California Press, Berkeley

Solarz W, Najberek K (2017) Alien parasites may survive even if their original hosts do not. EcoHealth 14:3-4

Solarz W, Najberek K, Pociecha A, Wilk-Woźniak E et al (2017) Birds and alien species dispersal: on the need to focus management efforts on primary introduction pathways - comment on Reynolds et al. and Green. Divers Distrib 23:113-117

Spatz D, Zilliacus K, Holmes N, Butchart S, Genovesi P, Ceballos G, Tershy B, Croll D (2017) Globally threatened vertebrates on islands with invasive species. Sci Adv 3:e1603080

Stone JK, Bacon CW, White JF (2000) An overview of endophytic microbes: endophytism defined. Microb Endophytes 3:29-33

Szewczyk K, Zidorn C, Biernasiuk A, Komsta Ł, Granica S (2016) Polyphenols from Impatiens (Balsaminaceae) and their antioxidant and antimicrobial activities. Ind Crops Prod 86:262-272

Tabak NM, von Wettberg E (2008) Native and introduced jewelweeds of the Northeast. Northeast Nat 15:159-176 
Tanner RA, Ellison CA, Seier MK, Kovács GM, Kassai-Jáger E, Berecky Z, Varia S, Djeddour D, Singh MC, Csiszár Á, Csontos P, Kiss L, Evans HC (2015) Puccinia komarovii var. glanduliferae var. nov.: a fungal agent for the biological control of Himalayan balsam (Impatiens glandulifera). Eur J Plant Pathol 141:247-266

Tekaia F, Latgé J-P (2005) Aspergillus fumigatus: saprophyte or pathogen? Curr Opin Microbiol 8:385-392

Ugoletti P, Stout JC, Jones MB (2011) Ecophysiological traits of invasive and non-invasive introduced Impatiens species. Biol Environ Proc R Ir Acad 111B:143-156

Ugoletti P, Reidy D, Jones MB, Stout JC (2013) Do native bees have the potential to promote interspecific pollination in introduced Impatiens species? J Pollinat Ecol 11:1-8

Valentine DH (1971) Flower-colour polymorphism in Impatiens glandulifera Royle. Boissiera 19:339-343

Vervoort A, Cawoy V, Jacquemart A-L (2011) Comparative reproductive biology in co-occurring invasive and native Impatiens species. Int J Plant Sci 172:366-377
Vilà M, Basnou C, Pyšek P, Josefsson M, Genovesi P, Gollasch S, Nentwig W, Olenin S, Roques A, Roy D, Hulme PE (2010) How well do we understand the impacts of alien species on ecosystem services? A pan-European, crosstaxa assessment. Front Ecol Environ 8:135-144

Vrchotová N, Šerá B, Krejčová J (2011) Allelopathic activity of extracts from Impatiens species. Plant Soil Environ 57:57-60

Waqas M, Khan A, Ali L, Kang S-M, Kim Y-H, Lee I-J (2013) Seed germination-influencing bioactive secondary metabolites secreted by the endophyte Cladosporium cladosporioides LWL5. Molecules 18:15519-15530

Watanabe T (2011) Pictorial atlas of soil and seed fungi: morphologies of cultured fungi and key to species. CRC Press, Washington, DC

Williamson M, Fitter A (1996) The varying success of invaders. Ecology 77:1661-1666 